\title{
Self-reported depression and sense of disease in cosmetic patients
}

Joanna Magdziarz-Orlitz'ㄹ, Zofia A. Gerlicz-Kowalczuk², Bożena Dziankowska-Bartkowiak²

\author{
1Solmed - Center of Aesthetic Medicine and Dermatology, Czestochowa, Poland \\ Head: Joanna Magdziarz-Orlitz MD, PhD \\ 2Department of Dermatology and Venereology, Medical University of Lodz, Poland \\ Head: Prof. Anna Sysa-Jędrzejowska MD, PhD
}

\begin{abstract}
Introduction: An increasing number of patients with various personality disorders, psychological problems and depression due to real or imaginary cosmetic defects visit a doctor.

Aim: Evaluation of the relationship between cosmetic problems and self-reported depression in individuals electing to undergo cosmetic procedures, sense of disease in these individuals as well as the relationship between selfreported disease and depression.

Material and methods: Investigations using Beck Depression Inventory (BDI) and Self-Esteem Scale (SES) were carried out on 167 patients, before and 4 weeks after the procedure.

Results: There is a statistically significant difference $(p<0.001)$ between mean values of measurements before ( 9.3 points) and after (6.12 points) surgical procedures. The percentage of patients with different severity of depression before the procedure decreased from $42 \%$ to $18 \%$. Using SES, the problem was assessed in the following categories: Obstacle, Challenge, Threat, Injustice, Benefit and Importance. The difference between mean scores before and following the intervention was 6.52 points and was statistically significant $(p<0.05)$.

Conclusions: The results obtained confirm that depression has an impact on self-reported disease and in the case of the investigated group it may be assumed that the aesthetic defect is a disease.
\end{abstract}

Key words: depression, sense of disease, cosmetic dermatology.

\section{Introduction}

The $21^{\text {st }}$ century is the era that values aesthetic beauty, thus, there is an increased interest in plastic surgery and particularly, noninvasive cosmetic procedures. An increasing number of patients undergo different cosmetic procedures to improve or eliminate aesthetic defects due to disease, aging or dissatisfaction with appearance. Successful cosmetic procedures depend on the patient's psychological condition. Sometimes, there are patients with personality disorders or psychological problems that influence their self-image.

\section{Aim}

Physical appearance, its self-perception as well as perception by other people directly influence a sense of wellbeing, sense of disease and may cause psychological problems such as depressive and personality disorders [1, 2]
Identifying psychological disorders is important as it helps to choose a proper therapy and increases effectiveness of the cosmetic procedure. At the same time, aesthetic defects are often perceived as having little significance as they do not pose any risk to health or life, however, they may be perceived as a disease by patients. Thus, the aim of the study was:

- to assess the relationship between aesthetic defects and self-reported depression in patients with aesthetic defects,

- to assess self-reported disease in individuals electing to undergo cosmetic procedures and assess the relationship between self-reported disease and depression.

\section{Material and methods}

The investigation was carried out on 167 patients with aesthetic defects: 149 females and 18 males aged

Address for correspondence: Zofia A. Gerlicz-Kowalczuk MD, Department of Immunodermatology, Medical University of Lodz, 5 Krzemieniecka, 94-017 Lodz, Poland, e-mail: zosia_gerlicz@yahoo.com 
18-72 years (mean age: 40.73 years, SD $=11.8$ ). Depending on the aesthetic problem, a proper therapy was instituted using the following methods: laser, botulinum toxin and hyaluronic acid, chemical exfoliation with trichloroacetic acid.

Exfoliation was performed in 27 patients, laser procedures in 18 patients and 122 patients underwent cosmetic procedures with hyaluronic acid and/or botulinum toxin (Table 1).

Information on the patient's general condition and no contraindications for the procedures mentioned above was elicited. Before and 4 weeks after the therapy,

Table 1. Clinical material

\begin{tabular}{lcc}
\hline Parameter & Number of patients $(n)$ & $\begin{array}{c}\text { Percentage } \\
\text { of patients }\end{array}$ \\
\hline Total & 167 & 100 \\
\hline Females & 149 & 89.2 \\
\hline Males & 18 & 10.8 \\
\hline Eductation: & 101 & 60.5 \\
\hline Higher & 57 & 34.1 \\
\hline Secondary & 8 & 4.8 \\
\hline Vocational & 1 & 0.6 \\
\hline Primary & 121 & 10.8 \\
\hline Place of living: & 46.5 \\
\hline City & 122 & 27.5 \\
\hline Country & & 73 \\
\hline Kind of procedure: & 18 & \\
\hline Cosmetic & & 16.2 \\
\hline Exfoliation & 122 & \\
\hline Laser & & \\
\hline
\end{tabular}

the patients filled in the questionnaires: 1) Self-Esteem Scale (SES), and 2) Beck Depression Inventory (BDI)

\section{Self-Esteem Scale}

Self-Esteem Scale is a questionnaire for assessing a person's overall evaluation of their disease. The patients answered on a five-grade answer scale: 5 -yes, 4 - rather yes, 3 - I do not know, 2 - rather not, 1 - no. Self-Esteem Scale comprises 47 items which make up seven subscales showing how important the sensation of the disease is: Threat, Benefit, Obstacle/loss, Challenge, Injustice, Value, Importance. Table 2 presents the description of subscales [3, 4].

\section{Beck Depression Inventory}

Beck Depression Inventory (BDI) is used for measuring severity of depression, rooted in the patient's own thoughts. It was designed to standardize depression severity, monitor its course and for an easy description of its progression. Its full version contains 21 most common symptoms of depression evaluated on a 4-grade scale of severity, scored on a scale value of 0-3 points. Total score shows depression severity and qualifies a patient for a particular group $[5,6]$. The highest score is 63 points. The cut-offs are as follows: 0-9 indicates no depression, 10-20 - mild depression, 21-30 - moderate depression, 31-40 - severe depression, 41-63 - very severe depression. The result below 4 points may suggest depression denial, total score higher than 63 - histrionic personality disorder or borderline [7].

The results obtained were calculated in accordance with the rules for a given scale. Descriptive statistics were used to describe the result distribution for a particular scale in the investigated group: arithmetic mean ( $x$ ), median (Me), standard deviation (SD). Pearson's linear correlation coefficient was used in the relationship analysis, $t$-Student test

Table 2. Description of Self-Esteem Scale

\begin{tabular}{|c|c|c|c|}
\hline Subscale No & Number of items & Question number & Description \\
\hline Threat & 8 & $1,8,15,22,29,36$ & $\begin{array}{l}\text { Disease destabilizes current life situation, causes anxiety about health } \\
\text { and social position }\end{array}$ \\
\hline Benefit & 7 & $2,9,16,23,30,37,43$ & $\begin{array}{l}\text { Disease is related to benefits: excuse from duty, responsibility, } \\
\text { generates a profit, fulfills need for interest, care and sympathy }\end{array}$ \\
\hline Obstacle/loss & 8 & $3,10,17,24,31,38,44,47$ & $\begin{array}{l}\text { Disease affects daily routine, family life, professional and social relationships, } \\
\text { interests, fitness, independence, possibilities and plans as well as causes } \\
\text { resignation from rewarding activities }\end{array}$ \\
\hline Challenge & 6 & $4,11,18,25,32,39$ & Disease is a difficult situation, it is an enemy to be eliminated \\
\hline Injustice & 7 & $5,12,19,26,33,40,45$ & Disease is a terrible fate, unmerited punishment and injustice \\
\hline Value & 6 & $6,13,20,27,34,41$ & Disease redefines current life, helps to find the deep sense of life \\
\hline Importance & 5 & $7,14,21,28,35$ & $\begin{array}{l}\text { Control subscale show how important the disease is, the lower the score } \\
\text { the less important the disease is perceived }\end{array}$ \\
\hline
\end{tabular}


Table 3. Distribution on the variable of Depression

\begin{tabular}{lcc}
\hline$x$ & 9.31 & 6.13 \\
\hline Me & 8 & 4 \\
\hline Min.-max. & $0-46$ & $0-43$ \\
\hline SD & 7.60 & 7.31 \\
\hline$x^{\prime}-x^{\prime \prime}$ & $3.18^{*}$ & \\
\hline$T$ & 10.93 &
\end{tabular}

*Statistically significant difference $(p<0.001), x$ - mean of measurements, $S D$ - standard deviation of measurement, Me - median, Min - minimal values, Max. - maximal values, $x^{\prime}-x^{\prime \prime}$ - difference of mean values in the first and second measurement, $t$-Student test value

was used to calculate the statistical significance of measurement difference before and after interventions.

\section{Results}

\section{Evaluation of depressive disorders according to Beck Depression Inventory}

Beck Depression Inventory was used to evaluate the severity of depressive disorders in patients after non-surgical procedures. Statistical analysis of the results showed that measurement before the procedure $\left(x^{\prime}=9.32\right)$ was higher than following the procedure $\left(x^{\prime \prime}=6.13\right)$. Analysis of distribution on the variable Depression demonstrated a statistically significant difference

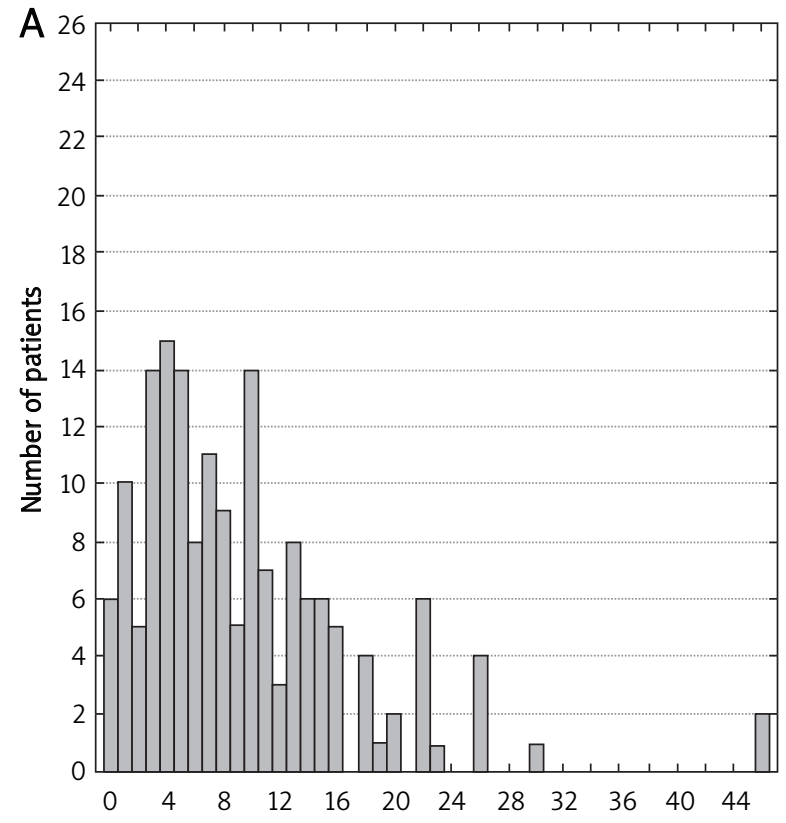

Measurement before procedures between the results obtained in the first and second measurements $\left(x^{\prime}-x^{\prime \prime}=3.18 ; p<0.001\right)$ (Table 3$)$.

Next, the score distribution obtained from patients with aesthetic problems was evaluated and compared with score distribution before and after the therapy. The score distribution of measurements before the procedure is comparatively even, while following the procedure, there was a shift of results to the right towards lower values (0-9 points) demonstrating no depression (Figure 1).

Before the procedure, the highest percentage of patients presented no depression symptoms - 58\% (97 patients), 33\% (56 patients) had mild depression, 7\% (12 patients) - moderate depression while a very severe depression was observed in only $1 \%$ of patients (Table 4 , Figure 2). After the cosmetic procedure, 82\% (137 patients) had no depression symptoms, 14\% (23 patients) - mild depression, 2\% (3 patients) - moderate depression, 1\% (2 patients) - severe depression and 1\% (2 patients) - very severe depression (Table 4, Figure 3).

\section{Evaluation of individuals' self-esteem}

To evaluate the aesthetic problem as a disease, SES was used as it makes it possible to see the disease as an event resulting in threat, anxiety, benefit (material or emotional), being a vital event or source of emotional damage or injustice. For statistical analysis, Wilcoxon test was used. There is a statistically significant difference $(p<0.05)$ between mean values obtained before and 4 weeks after the therapy

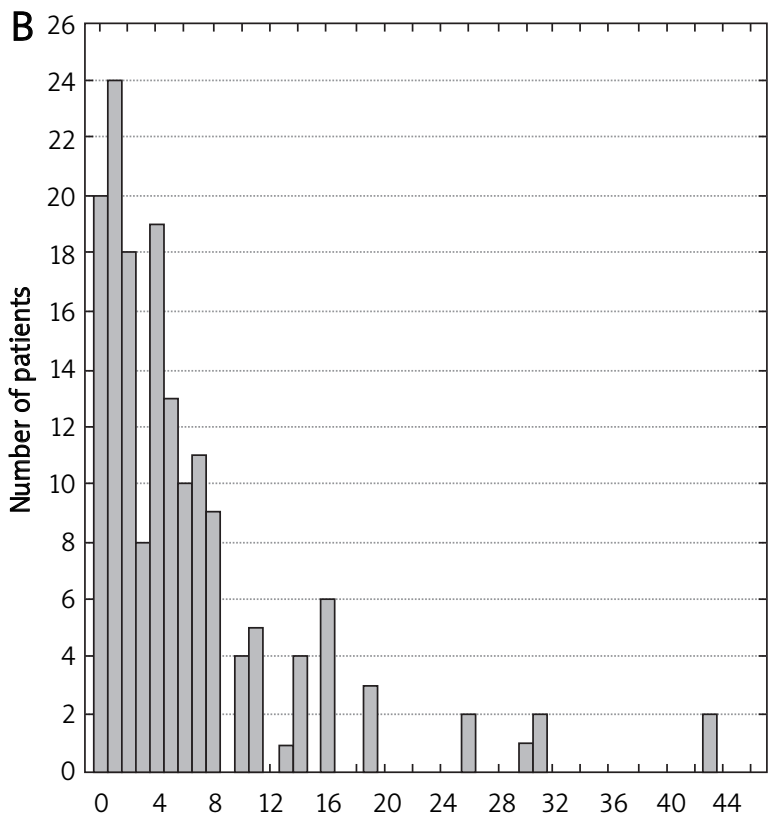

Measurement after procedures

Depression

Figure 1. BDI score distribution related to the number of patients measured before $(\mathrm{A})$ and after the procedure (B) 


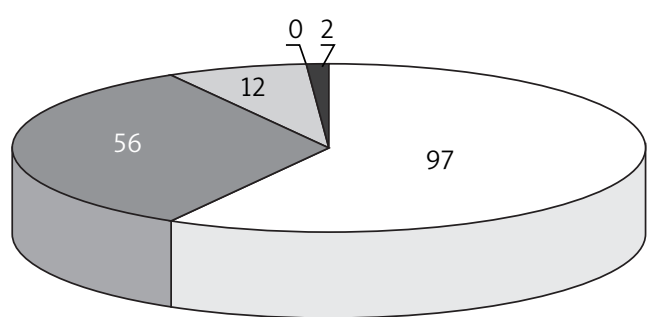

$\square$ No depression

Mild depression

$\square$ Moderate depression

$\mathbb{Z}$ Severe depression

Very severe depression

Figure 2. Number of patients related to depression severity before cosmetic procedures

(Table 5, Figure 4). The highest mean value before and after the therapy was related to Obstacle $\left(x^{\prime}=20.75, x^{\prime \prime}=19.04\right)$. Challenge also proved significant in self-assessment ( $x^{\prime}=$ $\left.20.36, x^{\prime \prime}=19.3\right)$. High results also apply to items Threat $\left(x^{\prime}=17.9, x^{\prime \prime}=16.55\right)$ and Injustice $\left(x^{\prime}=14.88, x^{\prime \prime}=13.94\right)$. Similar results were obtained for items Value $\left(x^{\prime}=12.97\right.$, $\left.x^{\prime \prime}=12.04\right)$, Importance $\left(x^{\prime}=12.52, x^{\prime \prime}=12.21\right)$, Benefit $\left(x^{\prime}=\right.$ $12.01, x^{\prime \prime}=11.57$ ) (Table 5, Figure 5). Differences in mean values were statistically significant $(p<0.05)$, however, there

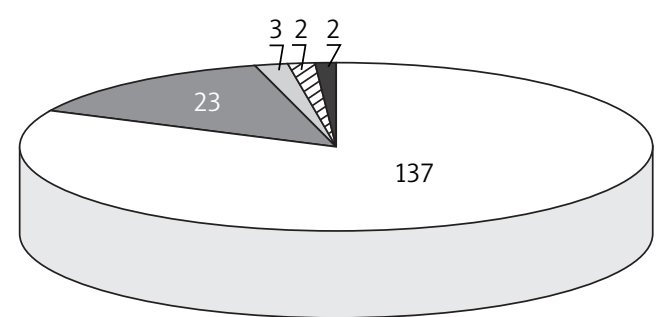

\begin{abstract}
$\square$ No depression
Mild depression

Moderate depression Severe depression

Very severe depression

Figure 3. Number of patients related to depression severity after cosmetic procedures
\end{abstract}

was no statistical significance in the analysis of Importance and Benefit (Table 5).

\section{Self-esteem related to depression}

The relationship between self-esteem (SES) and depression (using BDI) was evaluated. There were statistically significant correlations $(p<0.005)$ between depression severity and having an aesthetic problem regarding such items as Importance $(r=0.43)$ and Obsta-

Table 4. Analysis of Depression variable (severity, number of patients) before and after procedures

\begin{tabular}{lcccc}
\hline Severity of depression & \multicolumn{2}{c}{ Measurement before procedures } & \multicolumn{2}{c}{ Measurement after procedures } \\
\cline { 2 - 5 } & Number of patients & Percentage of patients & Number of patients & Percentage of patients \\
\hline No depression & 97 & 58.1 & 137 & 23 \\
\hline Mild & 56 & 33.5 & 3 & 13.8 \\
\hline Moderate & 12 & 7.2 & 2 & 1.8 \\
\hline Severe & 0 & 0.00 & 2 & 1.2 \\
\hline Very severe & 2 & 1.2 & 1.2 \\
\hline
\end{tabular}

Table 5. Mean values for patients using SES

\begin{tabular}{|c|c|c|c|c|c|c|}
\hline Variable & $x^{\prime}$ & $x^{\prime \prime}$ & $\mathrm{SD}^{\prime}$ & SD" & $x^{\prime}-x^{\prime \prime}$ & $T$ \\
\hline SES & 112.39 & 105.87 & 30.55 & 28.93 & 6.52 & $3.89^{*}$ \\
\hline Threat & 17.94 & 16.55 & 6.08 & 6.13 & $1.39^{*}$ & $3.42^{*}$ \\
\hline Benefit & 12.01 & 11.57 & 4.41 & 4.08 & 0.45 & 1.83 \\
\hline Obstacle/loss & 20.75 & 19.04 & 8.77 & 8.22 & 1.72 & $3.68^{\star}$ \\
\hline Challenge & 20.36 & 19.30 & 5.36 & 5.75 & 1.07 & $3.15^{\star}$ \\
\hline Injustice & 14.88 & 13.94 & 6.61 & 5.76 & 0.93 & $2.08^{\star}$ \\
\hline Value & 12.97 & 12.04 & 5.29 & 4.91 & 0.93 & $3.67^{*}$ \\
\hline Importance & 12.52 & 12.21 & 3.22 & 2.86 & 0.31 & 1.50 \\
\hline
\end{tabular}

*Statistically significant factors $(p<0.05), x$ '- mean value of the first measurement, $x$ "- mean value of the second measurement, SD'-standard deviation of the first measurement, SD" - standard deviation of the second measurement, $x^{\prime}-x$ " - the difference of mean values between the first and second measurements, $t-t$-Student test values 


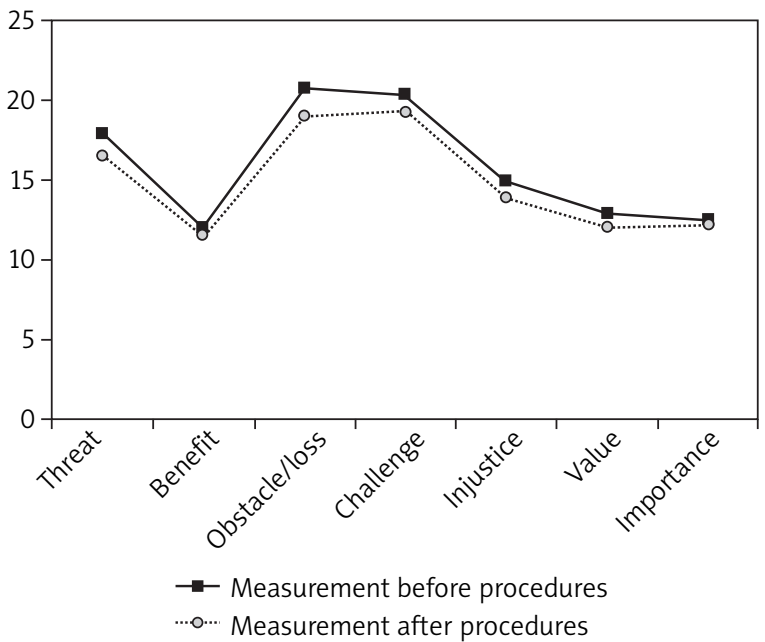

Figure 4. SES mean values

cle $(r=0.33)$. A statistically important relationship $(p<0.05)$ was found between BDI score and self-reported disease $(r=0.23)$. A slight positive and statistically significant correlation was also found between depression severity versus Injustice $(r=0.19)$ and Threat $(r=0.16)$ (Table 6).

\section{Discussion}

To-date investigations have shown that only a low percentage of patients with aesthetic problems electing to undergo a cosmetic procedure suffer from severe psychiatric problems [8]. Sometimes, patients with the body dysmorphic disorder, narcissistic or histrionic personality disorder, which affect their self-perception, want to have medical intervention [9-11]. At present, personality disorders are taken as permanent behavioral patterns, a form of self-assessment and attitude to other people, which, for their quality and quantity, affect social functioning, professional and personal development [12].

Patients with a body dysmorphic disorder (BDD) are excessively concerned with and preoccupied by a perceived defect in their physical features (body image) seen as deformed, unaesthetic, which is slight or not observed by other people $[12,13]$. Mostly, patients focus on their face, hair, nose and skin (scars, discolouration, wrinkles, reddening, pallor and other defects), however, this disorder may be linked to any part of the body. It may result in withdrawal, problems in everyday life, diminished quality of life, significant depressive disorder symptoms, including suicidal attempts [10, 13-17]. Patients with BDD often seek treatment from cosmetic surgeons, dermatologists or lately aesthetic dermatologists. According to Philips et al., 11.9\% of cosmetic patients suffer from body dysmorphia [18]. The number of patients with BDD ranges between $1 \%$ and $2 \%$ in the general population, however,

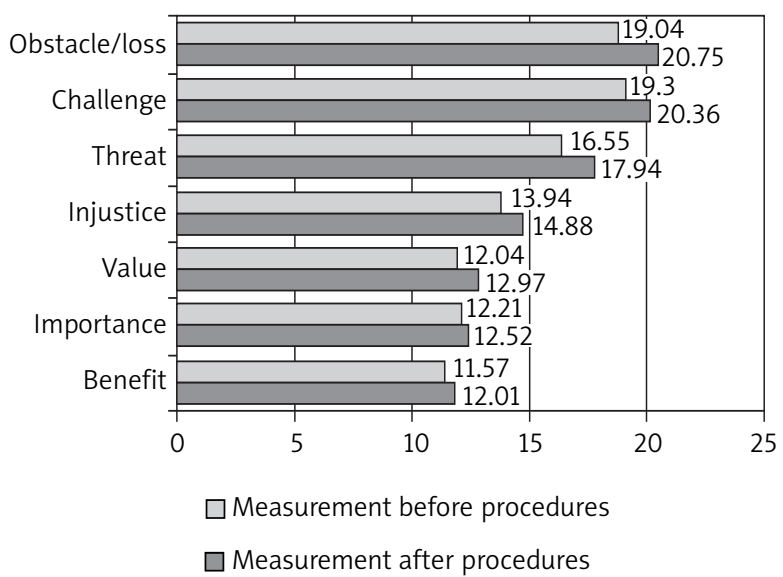

Figure 5. Mean values for the investigated group before and after cosmetic procedures

Table 6. Pearson's linear correlation ( $r$ ) between SES and BDI scores

\begin{tabular}{lc}
\hline Variable & Depression $r$ \\
\hline SES & $0.23^{*}$ \\
\hline SES threat & $0.16^{*}$ \\
\hline SES benefit & 0.06 \\
\hline SES obstacle/loss & $0.33^{*}$ \\
\hline SES challenge & -0.02 \\
\hline SES injustice & $0.19^{*}$ \\
\hline SES value & -0.05 \\
\hline SES importance & $0.43^{*}$ \\
\hline
\end{tabular}

*Statistically significant variable $(p<0.05), r$ - correlation coefficient

recent studies suggest that it may be higher $(2.9-16 \%)$ in patients undergoing cosmetic procedures $[17,18]$. Research shows that cosmetic procedures in patients with BDD are less effective. The patients get little satisfaction from the outcome and immediately request follow-up procedures or manifest dysmorphic symptoms related to other parts of the body $[13,17]$. These patients are not recommended for cosmetic procedures. They should be referred to a psychologist or/and a psychiatrist as BDD is a kind of obsessive-compulsive disorder (OCD). The dysmorphic syndrome is characterized by recurrent intrusive thoughts (obsession) or/and repetitive behaviors (compulsion). It may manifest as delusions and is recognized as hypochondriac psychosis (dermatologic hypochondria) and may be a precursor to schizophrenia $[13,14]$. In over $70 \%$ of patients with BDD, depressive disorders were found: dysthymia, major depressive disorder, fear disorders, social phobia or personality disorder [14]. 
Other disorders to be taken into consideration when referring a patient for a cosmetic procedure include narcissistic, histrionic or borderline personality. Histrionic personality disorder (Latin: histri - actor) is characterized by a pattern of excessive emotionality and attention seeking, including an excessive need for approval, may be easily influenced by others. Other features may include egocentrism, longing for appreciation, manipulative behavior to achieve their own needs, tendency to dramatize and exaggerate their difficulties. Histrionic personality is sometimes defined as infantile and more women than men are diagnosed with this personality disorder [18]. Munchausen syndrome is included by some authors in histrionic personality and results in auto-suggestion with hypochondriac features, self-destruction as well as a strong need to undergo surgical procedures [18].

The narcissistic personality disorder is characterized by being excessively preoccupied with personal power, prestige, tendency to exaggerate achievements, need for admiration, being preoccupied with fantasies of success, wealth, power, fame, beauty and ideal love, having a grandiose sense of self-importance, taking advantage of others to achieve their goals, being envious of others or believing others are envious of them. It is also characterized by showing arrogant behavior and attitudes, reacting strongly to criticism and by lack of empathy [19].

Borderline personality is described as emotionally unstable personality, characterized by lack of identity, marked impulsivity, involving unusual levels of instability in mood, changeability, self-harming behavior, aggression. It is placed between narcissistic and psychotic personalities. There is no precise definition of this personality disorder, clinically it is recognized as a stage between neurosis and psychosis [18].

Knowledge of characteristic features of personality disorders helps in making initial diagnosis, qualifying patients and choosing the proper therapy to achieve the best possible therapeutic results. Personality affects the quality of life and depression, which is an emotional disorder with basic, dominant feeling of sadness, dejection and discouragement [20]. Patients with depression often complain of somatic symptoms such as abdominal pains, headaches, back pains, dyspnea, itching, exhaustion, sleep disorders, drop in activity, tiredness. To diagnose depression, different information may be useful such as episodes of depression in the past or in the family, stressful events (death of a close relative/friend, divorce, fear of losing a job), alcohol abuse, sleep disorders [21]. It is difficult to diagnose depressive disorders; it requires a thorough and detailed interview using proper tools such as BDI, which is useful in diagnosing depressive as well as personality disorders (borderline or histrionic, BDI more than 40 points). In our own study, BDI higher than 40 points was found in 2 patients, both before and after the therapy.

Depression may be caused by a disease or somatic symptoms in the course of severe skin diseases: cancer or collagenosis. It may also accompany or appear in atopic dermatitis, lichen planus, psoriasis, acne vulgaris, rosacea, alopecia areata [22]. Aesthetic problems: scars, wrinkles, aging, physical appearance, striae, hirsutism, erythema, may also cause depression, although they are not a very severe problem compared to other skin or systemic diseases.

In our study, BDI score was 9.3 points before and 6.12 after the procedure, the difference was statistically significant $(p<0.001)$. The results are similar to literature data and according to BDI are as follows: 12 points for psoriasis, $12.11 \pm 7.50$ points for male pattern alopecia and $5.87 \pm 4.68$ points in the course of hidradenitis suppurativa [23-25]. In our study, $42 \%$ of patients suffered from depression of different severity before the therapy, which dropped to $18 \%$ after the intervention. Similar results were obtained after injecting botulinum toxin in depression treatment by relaxation of face muscles, particularly frown lines. The relationship between procedures preventing frowning and a decrease in the negative mood and negative emotions was found [26].

Investigation into depression severity in patients with aesthetic problems may contribute to a better quality of life of patients and their families as quality of life is related to depression [27]. The results obtained confirm favorable influence of aesthetic dermatology new techniques on a better quality of life. Depression accompanies many diseases. Steuden found that in people with depression, loneliness increases while satisfaction with life decreases as well as quality of life [28].

Most doctors focus on the physical examination and try to elicit physical symptoms from their patients. Psychological problems may be taken as problems of normal life [22]. Aesthetic dermatologists focus on the patient's problem, management and desired outcome. This approach may prevent from identifying psychological problems: personality or depressive disorders. That is why using a four-STEP program, which includes a psychological approach to a cosmetic patient, may be useful. The STEP program comprises:

- S - "Stress" - identifying stressors and making sure they are realistic and not exaggerated, finding tools and methods of coping with them and also patient's expectations.

- T - "Target" - the patient should define the goal, remodeling area and expected outcome.

- E - "Envision" - the patient should envision how much better emotions, perception, life will be after the surgical intervention.

- P - "Proactive" - if goals are realistic and achievable, a detailed plan of therapy should be designed [29].

Before performing a cosmetic procedure it is necessary to evaluate the patient's psychological condition. General assessment, posture, behavior and motivation may be helpful. Further diagnosis requires looking for subtle signs indicating potential problems but doctors should follow their intuition [28]. 
Co-operation with a psychologist or psychiatrist is recommended. However, a doctor should bear in mind that a person electing to undergo a cosmetic procedure should not be perceived as emotionally unstable or with personality disorders [30]. Most patients are healthy individuals who want to improve their appearance or remove defects.

Aesthetic problems such as wrinkles, loose skin, facial vascular abnormalities, striae, hirsutism or scars are perceived as being of little importance. Thus, it is interesting to find out if patients recognize their problem as a disease. In our study, we used the SES scale to assess it. The difference between the mean values obtained before and 4 weeks following the therapy was 6.52 points and was statistically significant $(p<0.05)$. The biggest, statistically significant $(p<0.05)$ differences between mean values before and after the therapy were related to Obstacle (20.75 points vs. 19.03 points), Challenge (20.36 points vs. 19.3 points), Threat (17.9 points vs. 16.55 points) and Injustice (14.88 points vs. 13.94 points). The results obtained are difficult to interpret. They may only be referred to investigations carried out by other authors using SES in the group of patients with psoriasis and other diseases as well as systemic sclerosis [4, 31]. The results according to SES varied. In his study Bogaczewicz obtained higher values in the following subscales: Threat, Obstacle, Injustice, Importance/value in patients with systemic sclerosis [30]. However, Janowski obtained higher values for patients with psoriasis in the subscales: Threat, Obstacle and in the case of other diseases: Threat, Obstacle and Challenge [4]. In our study, we obtained lower values in all subscales than in patients with the diseases mentioned above. The highest value was obtained for Challenge and Obstacle, which may demonstrate limitations patients may experience in relationships with other people, family or colleagues, after losing or having to change life plans. At the same time the problem is perceived as an enemy to be fought. In the investigated group, Threat value is high but relatively low when compared with the results obtained in the group of patients with psoriasis or other diseases. An aesthetic problem may be considered as threatening, causing anxiety about future appearance, aging, functioning, however, it is not threatening life or health. Despite low values of variables: Value, Importance and Benefit, an aesthetic problem cannot be interpreted as not important or trivial for the investigated patients. Certainly, the problem does not result in material and spiritual benefits or increase the attention and interest of other people. The investigated individuals reported increased interest of other people as nosy, rude and embarrassing. Thus, the variable Benefit is the lowest and confirms negative perception of the aesthetic problem. Evaluation of the aesthetic defect by patients, its importance or severity of disease may be verified assessing the correlation between values obtained using SES and BDI. We found a positive correlation, sta- tistically significant $(p<0.05)$ between variables Importance $(r=0.43)$, Obstacle $(r=0.33)$, Injustice $(r=0.19)$, Threat $(r=0.16)$. The results obtained confirm that depression affects self-esteem and in the investigated group it may be assumed that an aesthetic defect is a disease related to appearance. People with depression are not only less satisfied with their physical appearance but also with the shape and appearance of particular parts of the body [32].

\section{Conclusions}

In the investigated group, an aesthetic problem is perceived as negative and identified as a disease, mostly as an obstacle in family, professional and social lives. Even minor depressive disorders affect significantly self-esteem, diminish life quality, which result in stronger perception of an aesthetic defect and recognizing it as a disease.

The use of cosmetic procedures has been justified as there is a relationship between aesthetic problems and depression, which significantly diminished after cosmetic interventions. To-date observations demonstrate a significant influence of aesthetic problems related to appearance, skin and body condition as well as good looks on psyche, comparable to the influence of skin or systemic diseases.

\section{References}

1. Aarø LE, Herbeć A, Bjørngaard JH, et al. Depressive episodes and depressive tendencies among a sample of adults in Kielce, south-eastern Poland. Ann Agric Environ Med 2011; 18: 273-8.

2. Kołtątaj W, Sygit K, Sygit M, et al. Eating habits of children and adolescents from rural regions depending on gender, education, and economic status of parents. Ann Agric Environ Med 2011; 18: 393-7.

3. Rybienik B. Doświadczanie własnej choroby przez osoby z chorobą Parkinsona. KUL Instytut Psychologii, Lublin 2008.

4. Janowski K. Osobowościowe uwarunkowania radzenia sobie ze stresem w łuszczycy. Polihymnia, Lublin 2006; 101-4.

5. Kendall PC, Hollon SD, Beck AT, et al. Issue and recommendations regarding use of Beck Depression Inventory. Cognit Ther Res 1987; 11: 289-99.

6. Beck AT, Steer RA, Garbin MG. Psychometric properities of the Beck Depression Inventory: twenty-five years of evaluation. Clin Psychology Rev 1988; 8: 77-100.

7. Grygorczuk A. Związek zaburzeń depresyjnych nawracających z płcią psychologiczną i sposobami radzenia sobie w sytuacjach stresowych. Psychiatria. Via Medica, Gdańsk 2008; 5: 13-22.

8. Sarwer DB, Wadden TA, Pertschuk MJ, et al. Body image dissatisfaction and body dysmorphic disorder in 100 cosmetic surgery patients. Plast Reconstr Surg 1998; 101: 1644-9.

9. Most SP, Alsarraf R, Larrabee WF Jr. Outcomes of facial cosmetic procedures. Facial Plast Surg 2002; 18: 119-24.

10. Malick F, Howard J, Koo J. Understanding the psychology of the cosmetic patients. Dermatol Ther 2008; 21: 47-53. 
11. Ritvo EC, Melnick I, Marcus GR, Glick ID. Psychiatric conditions in cosmetic surgery patients. Facial Plast Surg 2006; 22: 194-7.

12. Ogłodek E, Moś D, Marek L, et al. Czy droga do piękna może być przymusem? Pol Merk Lek 2009; 27: 529-31.

13. Jabłońska E, Wojtczak K. Dysmorfofobia. Kryteria diagnostyczne, etiologia, rozpowszechnienie, obraz kliniczny, przebieg i leczenie. Psychiatria w Praktyce Ogólnolekarskiej 2006; 1: 42-9.

14. Sarwer DB, Crerand CE, Didie ER. Body dysmorphic disorder in cosmetic surgery patients. Facial Plast Surg 2003; 19: 7-18.

15. Conrado LA. Body dysmorphic disorder in dermatology: diagnosis, epidemiology and clinical aspects. An Bras Dermatol 2009; 84: 569-81.

16. Lai CS, Lee SS, Yeh YC, et al. Body dysmorphic disorder in patients with cosmetic surgery. Kaohsiung J Med Sci 2010; 26: 478-82.

17. Castle DJ, Phillips KA, Dufresne RG Jr. Body dysmorphic disorder and cosmetic dermatology: more than skin deep. J Cosmet Dermatol 2004; 3: 99-103.

18. Jakubik A. Zaburzenia osobowości. Wydawnictwo Lekarskie PZWL, Warszawa 2003; 72-96.

19. Ronningstam E. Narcissistic personality disorder: a current review. Curr Psychiatry Rep 2010; 12: 68-75.

20. Bidzan L. Depresyjne zaburzenia nastroju u osób w wieku podeszłym. Tom I. Psychiatria w Praktyce Klinicznej 2008; 1: 1-11.

21. Butwicka A, Gmitrowicz A. Różnice w występowaniu objawów somatycznych w przebiegu epizodu depresyjnego u kobiet i mężczyzn. Tom VI. Psychiatria w Praktyce Ogólnolekarskiej 2006; 4: 155-60.

22. Jakuszowiak K, Cubała W. Psychodermatologia w codziennej praktyce lekarskiej. Tom IV. Psychiatria w Praktyce Ogólnolekarskiej 2004; 3: 107-11.

23. Pietrzak A, Janowski K, Lechowska-Mazur I, et al. Łuszczyca jako przewlekła choroba skóry w kontekście psychologicznym. Nowa Medycyna 2006; 1: 14-9.

24. Rahimi-Ardabili B, Pourandarjani R, Habibollahi P, et al. Finasteride induced depression: a prospective study. BMC Clin Pharmacol 2006; 6: 7 .

25. Matusiak L, Bieniek A, Szepietowski JC. Psychophysical aspects of hidradenitis suppurativa. Acta Derm Venereol 2010; 90: 264-8.

26. Lewis MB, Bowler PJ. Botulinum toxin cosmetic therapy correlates with a more positive mood. J Cosmet Dermatol 2009; 8: 24-6.

27. Magdziarz-Orlitz J, Dziankowska-Bartkowiak B. Ocena wpływu wybranych technik dermatologii estetycznej na jakość życia badanych. Dermatol Estet 2011; 2: 98-105.

28. Steuden S, Szwajgier-Stączek. Poczucie osamotnienia a poczucie jakości życia u osób chorych na depresję. Jakość życia w chorobie. Wydawnictwo KUL 2007; 102-18.

29. Elsaie ML. Psychological approach in cosmetic dermatology for optimum patient satisfaction. Indian J Dermatol 2010; 55: $127-9$.

30. Ozgür F, Tuncali D, Güler Gürsu K. Life satisfaction, self-esteem, and body image: a psychosocial evaluation of aesthetic and reconstructive surgery candidates. Aesthetic Plast Surg 1998; 22: 412-9.

31. Bogaczewicz A. Analiza psychologicznych uwarunkowan jakości życia chorych na łuszczycę i twardzinę układową. Rozprawa doktorska, Łódź 2010.

32. Głębocka A. Niezadowolenie z wyglądu a rozpaczliwa kontrola wagi. Oficyna Wydawnicza Impuls, Kraków 2009. 